CLINICAL STUDY

\title{
A simple diagnostic test using GH-releasing peptide-2 in adult GH deficiency
}

\author{
Kazuo Chihara, Akira Shimatsu ${ }^{1}$, Naomi Hizuka ${ }^{2}$, Toshiaki Tanaka ${ }^{3}$, Yoshiki Seino ${ }^{4}$, Yuzuru Kato ${ }^{5}$ for the KP-102 \\ Study Group \\ Division of Endocrinology/Metabolism, Neurology, and Hematology/Oncology, Department of Clinical Molecular Medicine, Kobe University Graduate \\ School of Medicine, Kobe 650-0017, Japan, ${ }^{1}$ Clinical Research Institute, National Hospital Organization Kyoto Medical Center, Kyoto 612-8555, Japan, \\ ${ }^{2}$ Department of Medicine, Institute of Clinical Endocrinology, Tokyo Women's Medical University, Tokyo 162-8666, Japan, ${ }^{3}$ Division of Endocrinology and \\ Metabolism, National Center for Child Health and Development, Tokyo 154-8567, Japan, ${ }^{4}$ Osaka Kosei Nenkin Hospital, Osaka 553-0003, Japan and \\ ${ }^{5}$ Faculty of Medicine, University Hospital, Shimane University, Izumo 693-8501, Japan \\ (Correspondence should be addressed to K Chihara; Email: chiharak@med.kobe-u.ac.jp)
}

\begin{abstract}
Objective: The international, first-line diagnostic test for adult GH deficiency is the insulin tolerance test (ITT), which is contraindicated in some patients due to severe adverse events. Alternatives such as GH-releasing hormone combined with arginine or GH-releasing peptides (GHRP) have been proposed. We validated the use of GHRP-2 for diagnosing adult GH deficiency (GHD). Methods: Seventy-seven healthy subjects and 58 patients with peak $\mathrm{GH}<3 \mu \mathrm{g} / \mathrm{l}$ by ITT were enrolled. After overnight fasting, a $100 \mu \mathrm{g}$ dose of GHRP-2 was administered intravenously; blood samples were taken during the subsequent $2 \mathrm{~h}$ and $\mathrm{GH}$ measured by immunoradiometric assay.

Results: Serum GH peak occurred within 60 min after GHRP-2 administration in all subjects. GH responses to GHRP-2 were not affected by gender, but were slightly lower in elderly subjects and those with adiposity, although these did not influence diagnosis of GHD. Repeated tests showed favourable reproducibility. Peak GH concentrations after GHRP-2 were significantly $(P<0.001)$ lower in patients $(1.36 \pm 2.60 \mu \mathrm{g} / \mathrm{l})$ than the healthy group $(84.6 \pm 60.9 \mu \mathrm{g} / \mathrm{l})$ with no difference between hypothalamic and pituitary diseases. Serum GH concentration at the point where sensitivity of response crossed with specificity ranged from 15 to $20 \mu \mathrm{g} / \mathrm{l}$. A cut-off value of $15 \mu \mathrm{g} / \mathrm{l}$ for diagnosing GHD with GHRP-2 corresponded to the diagnostic value of $3 \mu \mathrm{g} / \mathrm{l}$ in the ITT.

Conclusions: The GHRP-2 provocative test showed favourable reproducibility and was mildly influenced by age and adiposity. Severe GH deficiency could be diagnosed with high reliability using a $15 \mu \mathrm{g} / \mathrm{l}(9 \mu \mathrm{g} / \mathrm{l}$ when GH calibrated with recombinant World Health Organization 98/574 standard) cut-off for peak GH concentration.
\end{abstract}

European Journal of Endocrinology 157 19-27

\section{Introduction}

With the increasing worldwide recognition that growth hormone $(\mathrm{GH})$ therapy is required at all stages of life for patients with GH deficiency (GHD), accurate diagnosis is required before commencing long-term treatment. GHD, in both adults and children, is diagnosed biochemically by provocative tests of GH secretory reserve (1); the insulin tolerance test (ITT) was accepted as the international, first-line diagnostic test of choice according to the consensus guidelines for the diagnosis and treatment of adults with GHD (2). The diagnostic criterion for GHD severe enough to warrant therapy was defined as a peak serum GH concentration $\left(C_{\max }\right)$ less than the arbitrary cut-off of $3 \mu \mathrm{g} / \mathrm{l}$ with the ITT (2).

An advantage of the ITT is that it allows the evaluation of the complete hypothalamic-pituitarysomatotroph axis, making it useful in patients with both hypothalamic and pituitary disease. However, there are a number of disadvantages to this test. GH secretion is induced by hypoglycaemia, so there is a potential for hypoglycaemia-related adverse reactions (3). It is contraindicated in patients with coronary or cerebrovascular disease, a history of ischaemic heart disease or any convulsive disease and particular attention is needed for the elderly (3). Furthermore, it was reported that the reproducibility of the GH response in an ITT was not sufficient (4-6); a false-negative result, suggestive of insufficient GH secretion, was sometimes obtained even in normal subjects and this was particularly influenced by age and adiposity (7). ITT needs multiple blood sampling and requires close monitoring of patients for several hours in a specialised investigation unit. Thus, there is a need for a simple effective test to establish GHD.

Many other GH provocative tests are employed in clinical practice. The combination of arginine plus GH-releasing hormone (GHRH) has been proposed as a 
useful, reproducible, alternative test to the ITT $(8,9)$. It is not affected by age but by gender and adiposity (9, 10). Patients with primary hypothalamic disease, such as radiation-induced GHD, may exhibit false-positive responses to the arginine plus GHRH test $(11,12)$.

Use of a group of peptides called GH-releasing peptides (GHRP) has also been investigated, either alone or in combination with GHRH (13-15). GHRPs are synthetic secretagogues (16) that elicit a dose-dependent and specific GH release by binding to a specific receptor, for which ghrelin has been shown to be the natural ligand (17). The combined GHRH plus GHRP test has been shown to be well tolerated and sensitive in diagnosing GHD (13-15). The influences of age and adiposity have been investigated $(18,19)$, but more studies are needed to confirm these findings. GHRP-2 has the structure: D-alanyl-3-(2-naphthyl)-D-alanyl-L-alanyl-L-tryptophylD-phenylalanyl-L-lysinamide dihydrochloride and is one of the most potent GHRPs (20). Pre-clinical studies demonstrated that its GH-stimulating effect was attenuated when the hypothalamic/pituitary gland connection was impaired $(21,22)$. In the present communication, we report clinical studies in GHdeficient patients, as well as healthy adult subjects, to validate the use of a single dose of GHRP-2 as a diagnostic agent for GHD resulting from hypothalamic or pituitary disease.

\section{Subjects and methods}

\section{Subjects}

A total of 135 subjects were enrolled in this study, comprising 58 patients previously diagnosed as having severe GHD, from a peak serum $\mathrm{GH}$ value of $<3 \mu \mathrm{g} / \mathrm{l}$ in ITT, and 77 healthy adult subjects enrolled as a control group. Patients were excluded from the study for the following reasons: accompanying hypothyroidism or central diabetes insipidus not treated with adequate substitution therapy, receiving a GH preparation, presence of a chromosome abnormality or a serious complication and pregnancy or possible pregnancy. Efforts were made to recruit patients with hypothalamic and pituitary stalk diseases in the study to validate the efficacy of GHRP-2. Prior to starting the study, approval was obtained from the Institutional Review Board of each medical institution and written informed consent was obtained from each subject.

The 77 healthy subjects included 53 males and 24 females, with an age range from 20 to 76 years (median: 26 years) and a body mass index (BMI) ranging from 13.9 to $36.2 \mathrm{~kg} / \mathrm{m}^{2}$ (median: $22.0 \mathrm{~kg} / \mathrm{m}^{2}$ ). The subjects included six males, who were classified as overweight (obesity grade 1 by Japanese criteria (23)), with a $\mathrm{BMI} \geq 25 \mathrm{~kg} / \mathrm{m}^{2}$ and $<30 \mathrm{~kg} / \mathrm{m}^{2}$ (median: $25.7 \mathrm{~kg}$ ) $\mathrm{m}^{2}$ ), and six males classified as obese (obesity grade 2 by Japanese criteria, with a BMI $\geq 30 \mathrm{~kg} / \mathrm{m}^{2}$ (median: $\left.33.3 \mathrm{~kg} / \mathrm{m}^{2}\right)$ ).

The 58 patients with severe GHD comprised 37 males and 21 females, with an age range from 17 to 64 years (median: 39 years) and a BMI ranging from 19.5 to $30.3 \mathrm{~kg} / \mathrm{m}^{2}$ (median: $24.4 \mathrm{~kg} / \mathrm{m}^{2}$ ). There were no statistically significant differences in gender or age between the healthy control subjects and the GH-deficient patients; however, the BMI was significantly higher in the patient group $(P=0.001)$. Table 1 shows the pertinent clinical data of the patients with GHD; serum IGF-1 s.D. score was calculated according to the recently established normative data from 1110 healthy Japanese adult (24). The most common tumour was germinoma $(n=18)$ reflecting the relatively high prevalence of this tumour type in Japan (25). Two out of the thirteen patients with craniopharyngioma and all 18 with germinoma had previous cranial irradiation.

Table 1 Clinical data of the patients with severe GH deficiency.

\begin{tabular}{|c|c|c|c|c|c|c|c|c|c|}
\hline \multirow[b]{2}{*}{ Etiology } & \multirow[b]{2}{*}{ Number } & \multirow[b]{2}{*}{$\begin{array}{l}\text { Gender } \\
(\mathrm{M} / \mathrm{F})\end{array}$} & \multirow{2}{*}{$\begin{array}{c}\text { Age } \\
\text { median } \\
\text { (range) }\end{array}$} & \multirow[b]{2}{*}{$\begin{array}{c}\text { BMI } \\
\text { mean } \pm \text { s.D. }\end{array}$} & \multirow[b]{2}{*}{$\begin{array}{l}\text { IGF-1 s.D. score } \\
\text { median (range) }\end{array}$} & \multicolumn{4}{|c|}{ Hormonal replacement $^{a}$} \\
\hline & & & & & & $1 \mathrm{H}$ & $2 \mathrm{H}$ & $3 \mathrm{H}$ & DDAVP \\
\hline \multicolumn{10}{|c|}{ Primary pituitary diseases } \\
\hline Adenoma & 10 & $8 / 2$ & $47(31: 60)$ & $24.8 \pm 2.7$ & $-2.06(-7.15:-0.53)$ & 2 & 2 & 5 & 2 \\
\hline Sheehan syndrome & 4 & $0 / 4$ & $(40: 62)$ & $22.7 \pm 3.8$ & $(-6.88:-1.24)$ & 0 & 3 & 1 & 0 \\
\hline Others $^{c}$ & 5 & $4 / 1$ & $41(31: 63)$ & $26.0 \pm 3.5$ & $-4.00(-6.48:-0.65)$ & 0 & 1 & 3 & 2 \\
\hline \multicolumn{10}{|c|}{ Primary hypothalamic diseases } \\
\hline Craniopharyngioma $^{\mathrm{d}}$ & 13 & $6 / 7$ & $31(17: 64)$ & $22.8+2.4$ & $-3.68(-8.97:-0.16)$ & 1 & 3 & 8 & 7 \\
\hline Germinoma $^{d}$ & 18 & $11 / 7$ & $32(22: 47)$ & $25.3 \pm 3.1$ & $-3.06(-11.81: 0.23)$ & 2 & 6 & 7 & 14 \\
\hline $\begin{array}{l}\text { Pituitary stalk } \\
\text { transection }\end{array}$ & 5 & $5 / 0$ & $28(20: 41)$ & $23.0 \pm 2.1$ & $-3.74(-5.33:-2.29)$ & 0 & 1 & 4 & 1 \\
\hline Others $^{\mathrm{e}}$ & 3 & $3 / 0$ & $(48: 60)$ & $26.8 \pm 1.5$ & $(-3.93:-0.99)$ & 0 & 3 & 0 & 3 \\
\hline
\end{tabular}

$\mathrm{a}_{1} \mathrm{H} / 2 \mathrm{H} / 3 \mathrm{H}$-number of pituitary hormone replacements (thyroid hormone, glucocorticoid, sex steroids).

bIncluded eight non-functioning adenoma, one Cushing's disease and one prolactinoma.

'Included two idiopathic, two trauma and one Rathke's cleft cyst.

dTwo craniopharyngioma and all 18 germinoma patients received cranial irradiation.

e Included two Langerhans cell histiocytosis and one hypertrophic pachymeningitis. 


\section{GH provocative tests}

ITT All 58 patients with severe GHD were diagnosed by ITT. After overnight fasting, regular insulin (0.05$0.1 \mathrm{U} / \mathrm{kg}$ ) was administered via an antecubital vein, blood samples were drawn before and 30, 45, 60, 90 and $120 \mathrm{~min}$ after insulin injection and serum $\mathrm{GH}$ concentrations were determined. All patients reached the required levels of hypoglycaemia $(<2.2 \mathrm{nmol} / \mathrm{l})$ and had clinical signs of hypoglycaemia.

GHRP-2 test A single dose of GHRP-2 (KP-102, Kaken Pharmaceuticals, Tokyo, Japan) was given to each of the subjects under fasting conditions. The GHRP-2 was administered intravenously at a dose of $100 \mu \mathrm{g}$. In order to investigate the reproducibility of $\mathrm{GH}$ secretion induced by GHRP-2, three doses $(25,50$ and $100 \mu \mathrm{g})$ were re-administered to 21 healthy subjects with 4-week washout periods between testing.

Blood samples were taken before and 15, 30, 45, 60, 90 and $120 \mathrm{~min}$ after GHRP-2 administration and the serum GH concentrations were determined. For evaluation of safety of GHRP-2, blood pressure and heart rate were measured and laboratory tests of haematology and blood chemistry were performed before and after administration.

\section{GH determination}

GH concentrations were measured using an IRMA kit (Daiichi Radio Isotope Research Institute, Tokyo, Japan) calibrated with GH standard WHO IRP 66/217. The peak values of serum $\mathrm{GH}$ concentration $\left(C_{\text {max }}\right)$ were standardised with the formula established by the Foundation for Growth Science in Japan to adjust for the inter-assay kit variations (26). However, recent changes have resulted in the use of a new standard, WHO 98/574, in Japan, whereby vales are to be revised by multiplying by 0.6 (27). Values below the detection limit $(<0.05 \mu \mathrm{g} / \mathrm{l})$ were handled as $0.05 \mu \mathrm{g} / \mathrm{l}$.

\section{Data analysis}

The data were expressed as mean \pm s.D. if normally distributed or as median and ranges if the data were skewed. Differences between groups were examined by $\chi^{2}$ or $t$-tests. Kruskal-Wallis one-way ANOVA was used to compare normally distributed multiple independent groups, whereas ANOVA on ranks was used if the data were skewed. A $P$ value $<0.05$ was taken as significant. The receiver-operating characteristics (ROC) and sensitivity-specificity curves were investigated to establish the standard $C_{\max }$ value for diagnosis of $\mathrm{GH}$ deficiency with GHRP-2. For evaluation of two-variable conformance, the figure obtained by plotting the difference between $C_{\max }$ values (logarithm) of serum $\mathrm{GH}$ obtained with GHRP-2 and insulin against each mean $C_{\max }$ value (logarithm) (Bland-Altman plot; (28)) was used for the comparison of response intensity between GHRP-2 and insulin.

\section{Results}

Figure 1 shows the serum $\mathrm{GH} C_{\max }$ value in each subject after the administration of GHRP-2. In the control group, the $C_{\max }$ was $87.4 \pm 62.9 \mu \mathrm{g} / \mathrm{l}$ (range: 15.9-345.1 $\mu \mathrm{g} / \mathrm{l}$; median: $69.9 \mu \mathrm{g} / \mathrm{l})$. In the patient group, the $C_{\max }$ for serum $\mathrm{GH}$ was $1.36 \pm 2.60 \mu \mathrm{g} / \mathrm{l}$ (range: $0.05-14.8 \mu \mathrm{g} / \mathrm{l}$; median: $0.38 \mu \mathrm{g} / \mathrm{l}$ ). The $C_{\max }$ value was significantly higher in the control group than in the patient group $(P<0.001)$ and was not more than $15 \mu \mathrm{g} / \mathrm{l}$ in any of the 58 patients, but was not $<15 \mu \mathrm{g} / \mathrm{l}$ in any of the 77 subjects in the control group.

The influences of age, gender and adiposity on $\mathrm{GH}$ response to GHRP-2 were analysed for all 77 control subjects and the results are shown in Table 2. There were no significant differences in $\mathrm{GH} C_{\max }$ between males and females in the age range 20-59 years, and between preand post-menopausal females in the age range 40-59 years. A small differences in the $C_{\max }$ of serum $\mathrm{GH}$ was observed between males and females aged over 60 years $(P=0.030)$. Among the three age groups assessed, significant differences were observed; the $\mathrm{GH} C_{\max }$ was higher in the age group of 20-39 years than in the age group of $40-59$ years $(P<0.001)$ and over 60 years $(P<0.001)$. A significant difference was also observed between overweight $\left(\mathrm{BMI} \geq 25 \mathrm{~kg} / \mathrm{m}^{2}\right.$ and $<30 \mathrm{~kg} / \mathrm{m}^{2}$; $P<0.001)$ or obese (BMI $\left.\geq 30 \mathrm{~kg} / \mathrm{m}^{2} ; P=0.019\right)$ subjects and lean $\left(\mathrm{BMI}<25 \mathrm{~kg} / \mathrm{m}^{2}\right)$ subjects in the age group 20-39 years. In the age group $>40$ years, BMI affected the $C_{\text {max }}$ of serum GH even within lean $\left(\mathrm{BMI}<25 \mathrm{~kg} / \mathrm{m}^{2}\right)$

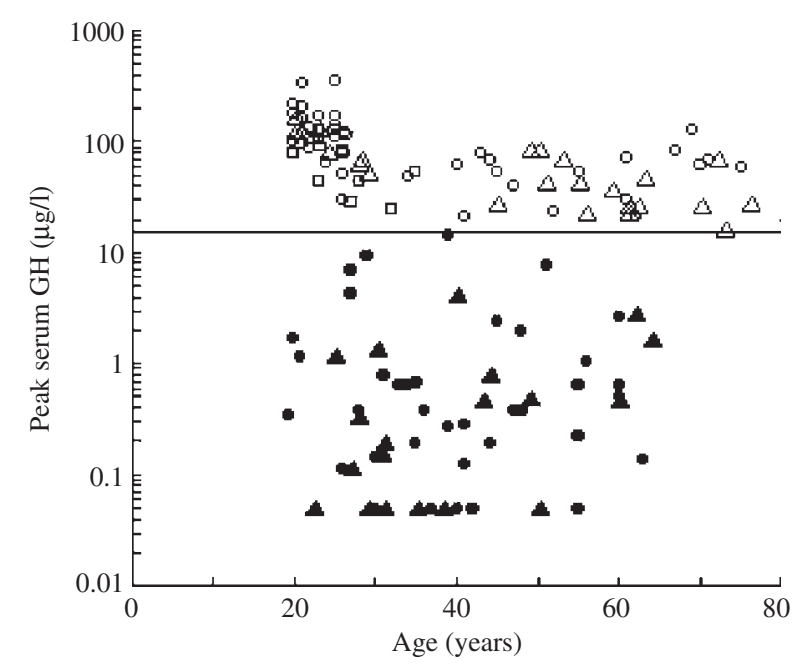

Figure 1 Individual peak GH concentrations after GHRP-2 administration in control subjects and patients with severe GHD defined from an ITT; the horizontal dotted line shows the value of $15 \mu \mathrm{g} / \mathrm{l}$. 
Table 2 Effects of age, gender and menopause, and age and body mass index (BMI), on peak serum growth hormone (GH) concentration $\left(C_{\max }\right)$ following $\mathrm{GH}-$ releasing peptides-2 administration to healthy control subjects.

\begin{tabular}{|c|c|c|c|c|}
\hline & $n$ & $C_{\max }(\mu \mathrm{g} / \mathrm{l})$ & Median (range) & \\
\hline \multicolumn{5}{|c|}{ Age, gender and menopause } \\
\hline $20-39$ years & 45 & $114.3 \pm 67.5$ & $104.9(24.2-345.1)$ & \\
\hline Male & 37 & $117.0 \pm 72.2$ & $104.9(24.2-345.1)$ & \\
\hline Female & 8 & $101.5 \pm 40.6$ & $97.8(51.6-167.9)$ & \\
\hline $40-59$ years & 16 & $50.3 \pm 22.0$ & $47.5(20.9-85.6)$ & $P<0.001$ vs $20-39$ years \\
\hline Male & 8 & $49.2 \pm 20.4$ & $52.1(20.9-78.8)$ & $P<0.001$ vs $20-39$ years male \\
\hline Female & 8 & $51.5 \pm 24.9$ & $43.2(22.8-85.6)$ & $P=0.010$ vs $20-39$ years female \\
\hline Pre-menopause & 4 & $60.2 \pm 29.6$ & $(27.4-85.6)$ & \\
\hline Post-menopause & 4 & $42.9 \pm 19.1$ & $(22.8-68.8)$ & \\
\hline $60-76$ years & 16 & $48.7 \pm 30.6$ & $38.1(15.9-130.5)$ & $P<0.001$ vs $20-39$ years \\
\hline Male & 8 & $64.8 \pm 33.4$ & $63.8(21.4-130.5)$ & $P=0.005$ vs $20-39$ years male \\
\hline Female & 8 & $32.6 \pm 17.3$ & $26.4(15.9-69.3)$ & $\begin{array}{l}P=0.002 \text { vs } 20-39 \text { years female } \\
P=0.030 \text { vs } 60-76 \text { years male }\end{array}$ \\
\hline \multicolumn{5}{|l|}{$\begin{array}{l}\text { Age and BMI } \\
20-39 \text { years }\end{array}$} \\
\hline$\leq 21.9 \mathrm{~kg} / \mathrm{m}^{2}$ & 22 & $121.2 \pm 59.3$ & $115.4(29.9-329.4)$ & \\
\hline $22-24.9 \mathrm{~kg} / \mathrm{m}^{2}$ & 14 & $138.1 \pm 81.0$ & $124.5(48.6-345.1)$ & \\
\hline$\geq 25 \mathrm{~kg} / \mathrm{m}^{2}$ & 9 & $60.2 \pm 27.8$ & $52.3(24.2-101.2)$ & $P<0.001$ vs $\leq 21.9 \mathrm{~kg} / \mathrm{m}^{2}, 22-24.9 \mathrm{~kg} / \mathrm{m}^{2}$ \\
\hline$\geq 30 \mathrm{~kg} / \mathrm{m}^{2}$ & 6 & $58.1 \pm 27.0$ & $48.2(28.1-101.2)$ & $P=0.019$ vs $\leq 21.9 \mathrm{~kg} / \mathrm{m}^{2}, 22-24.9 \mathrm{~kg} / \mathrm{m}^{2}$ \\
\hline \multicolumn{5}{|l|}{$40-76$ years } \\
\hline$\leq 21.9 \mathrm{~kg} / \mathrm{m}^{2}$ & 10 & $67.4 \pm 28.0$ & $64.9(29.2-130.5)$ & \\
\hline $22-24.9 \mathrm{~kg} / \mathrm{m}^{2}$ & 19 & $41.9 \pm 21.2$ & $37.0(15.9-85.6)$ & $P=0.0106$ vs $\leq 21.9 \mathrm{~kg} / \mathrm{m}^{2}$ \\
\hline$\geq 25 \mathrm{~kg} / \mathrm{m}^{2}$ & 3 & $37.9 \pm 27.2$ & (21.4-69.3) & \\
\hline
\end{tabular}

subjects. Analysis of the area under the curve (AUC) values for serum $\mathrm{GH}$ concentration against time after administration (data not shown) showed similar trends to the analysis of $C_{\max }$ values.

In 21 male control subjects, aged 20-29 years, various doses of GHRP-2 $(25,50$ and $100 \mu \mathrm{g})$ were administered twice to investigate the reproducibility of GH response. The correlation between peak $\mathrm{GH}$ values from the first and second injections are shown in Fig. 2. Marked interindividual variations of GH responses to GHRP-2 appeared to blunt the dose-related increase in $\mathrm{GH}$ secretion. However, the Spearman correlation coefficient for $C_{\max }$ was 0.89 , indicating favourable reproducibility.

Figure 3 shows a scatter diagram in which the 58 patients with a peak serum GH value $<3 \mu \mathrm{g} / \mathrm{l}$ in the ITT are plotted on the horizontal axis, in the increasing order of $C_{\max }$, with the corresponding serum $\mathrm{GH} C_{\max }$ values after administration of GHRP-2. Most of the patients, whose $C_{\max }$ value was less than the detection limit in the ITT showed almost no response to GHRP-2 and seven of the patients, whose $C_{\max }$ was higher than $0.5 \mu \mathrm{g} / \mathrm{l}$ in the ITT showed a $C_{\max }$ value higher than $3 \mu \mathrm{g} / \mathrm{l}$ in response to GHRP-2.

GHD patients were divided by underlying primary causes according to the presumed hypothalamic or pituitary origin. Presumed hypothalamic causes were craniopharyngioma, germinoma, pituitary stalk transection and other hypothalamic tumour such as Langerhans cell histiocytosis; presumed pituitary causes included pituitary adenoma, Sheehan syndrome and other causes. Figure 4 summarises the results of $C_{\max }$ in control subjects and in patients with presumed primary hypothalamic and pituitary diseases according to the age group of 17-39 years or $\geq 40$ years. Both hypothalamic and pituitary diseases showed equally attenuated GH responses to GHRP-2 irrespective of the age.

Table 3 shows the results for peak serum GH in patients with GHD and in controls stratified by age and BMI because $C_{\max }$ was dependent on both parameters in healthy subjects. There was no overlap between peak $\mathrm{GH}$ values in the patient group and the corresponding control group. Table 4 shows the time of peak serum GH

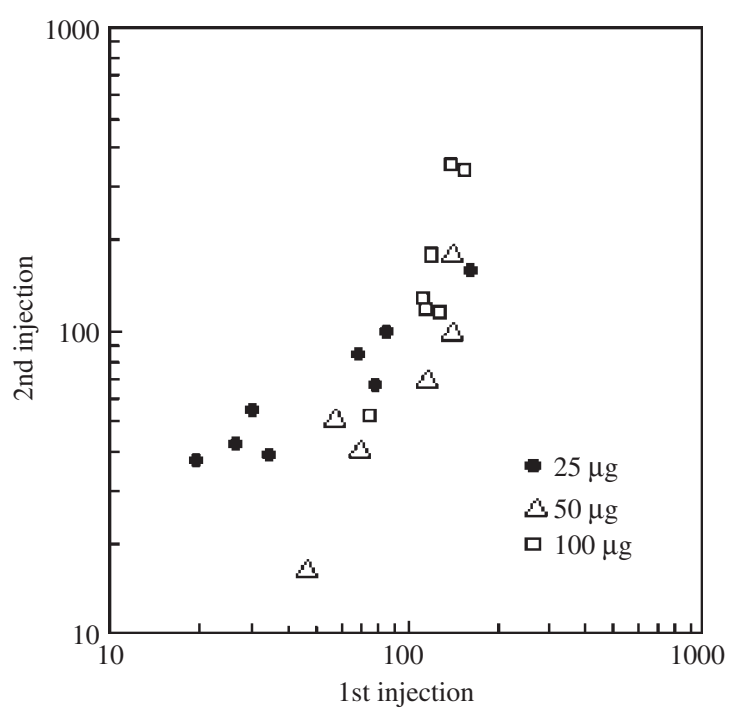

Figure 2 Correlation between peak $\mathrm{GH}$ values after the first and second injections of GHRP-2, at doses of 25, 50 and $100 \mu \mathrm{g}$, in healthy control subjects. 


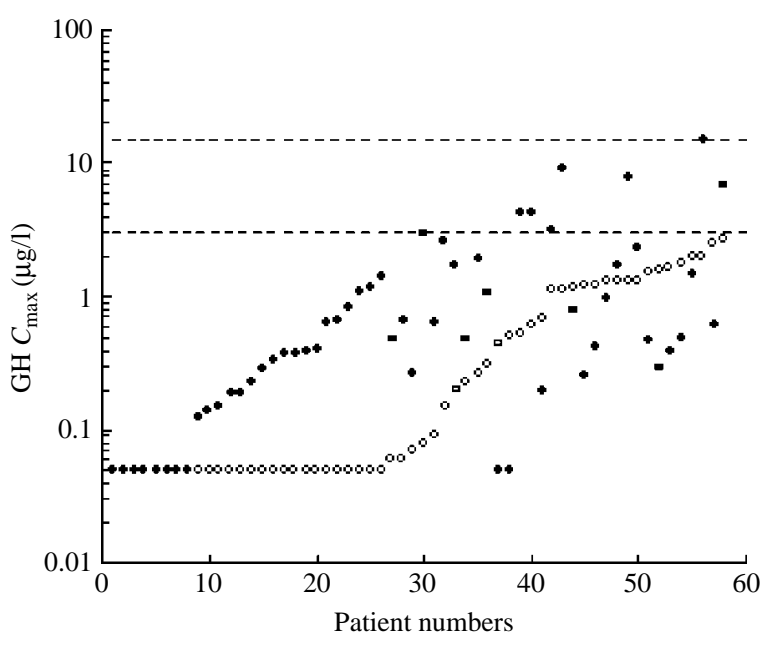

Figure 3 Comparison of peak GH values during an ITT (open symbols) and after GHRP-2 administration (closed symbols), in patients with severe GHD; horizontal dotted lines show 15 and $3 \mu \mathrm{g} / \mathrm{l}$.

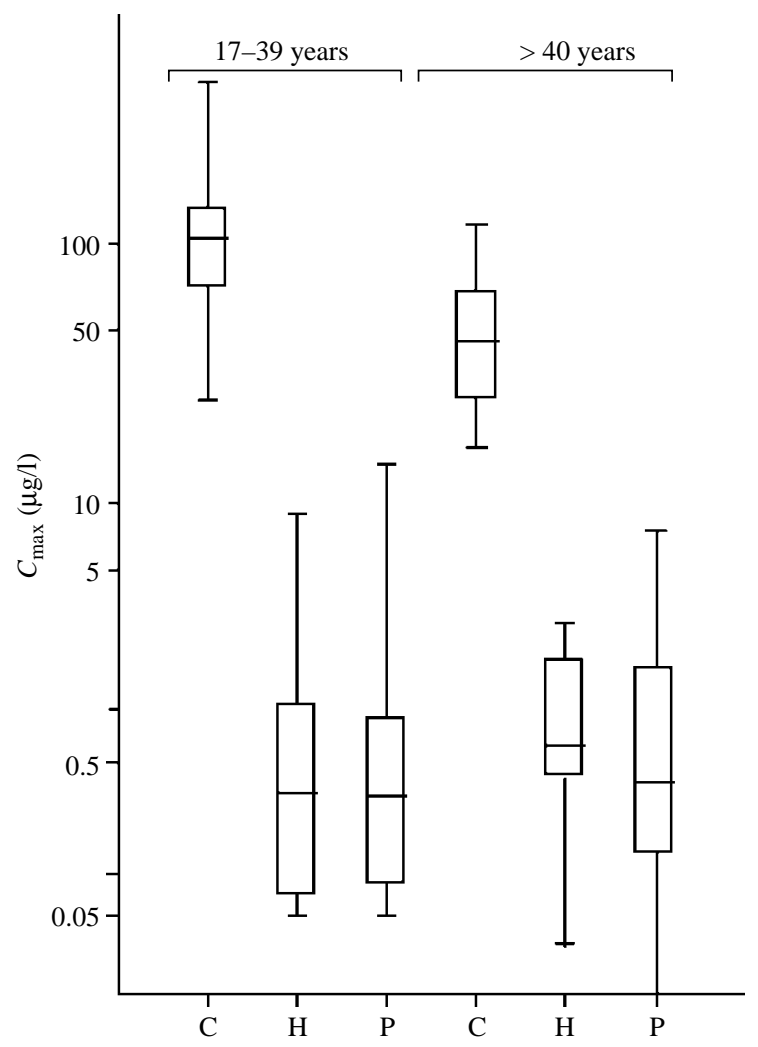

Figure 4 Box and whisker plots representing peak GH responses $\left(C_{\max }\right)$ to GHRP-2 in control subjects $(C)$ and GHD patients with presumed primary hypothalamic $(\mathrm{H})$ and pituitary $(\mathrm{P})$ diseases; the horizontal line in the box indicates the median, the lower and upper boundaries of the box indicate the 25th and 75th percentiles and error bars above and below the box indicate the 97.5 th and 2.5 th percentiles. concentration $\left(T_{\max }\right)$ after the administration of GHRP-2. The peak value was seen within 15 min after administration in $74 \%(43 / 58)$ of the GH-deficient patients and within $30 \mathrm{~min}$ in $88 \%(68 / 77)$ of the control subjects. The peak value was seen within 60 min after the administration in all 132 subjects, except for three of the control group who showed GH peak at $60 \mathrm{~min}$ after GHRP-2 administration. When the serum GH concentration at $30 \mathrm{~min}\left(C_{30 \mathrm{~min}}\right)$ was compared with the peak serum $\mathrm{GH}$ concentration $\left(C_{\text {max }}\right)$ during the GHRP-2 test, both values were almost of the same magnitude (Fig. 5) with no overlap for $C_{30 \text { min }}$ between the patient and control group.

In order to set a cut-off value for diagnosis of GHD with GHRP-2, the sensitivity and specificity on changing the assumed cut-off value were evaluated as an ROC curve and as a sensitivity-specificity curve. The AUC of the ROC curve was close to 1 (Fig. 6), confirming that GHRP-2 showed high precision as a diagnostic agent for GH secretory capacity. In the sensitivityspecificity curve (Fig. 6), the serum GH concentration at the point where the sensitivity crossed with the specificity, i.e. the borderline value showing both high sensitivity and high specificity, ranged from 15 to $20 \mu \mathrm{g} / \mathrm{l}$, if all patients were included. This was consistent with the results of the Bland-Altman analysis (data not shown) performed to compare the GH secretory capacity of GHRP-2 with that of insulin. The mean difference in $C_{\max }$ of serum $\mathrm{GH}$ between GHRP-2 and insulin was 0.702; in retro-conversion, this means that the GH secretion capacity of GHRP-2 was 5.03 times higher than that of insulin. Based on the above results, it was considered reasonable to set the cut-off value for diagnosis of severe GHD with GHRP-2 at $15 \mu \mathrm{g} / \mathrm{l}$, corresponding to the cut-off value of $3 \mu \mathrm{g} / \mathrm{l}$ for the diagnosis by ITT.

The adverse reactions noted after the administration of GHRP-2 are shown in Table 5. Adverse reactions were reported by 31 of the 58 subjects $(53.4 \%, 45$ episodes) in the patient group and 23 of the 77 subjects (29.9\%, 34 episodes) in the control group, i.e. in 54 of the 135 subjects $(40.0 \%, 79$ episodes $)$ in total. The major adverse reactions were hot flush, borborygmus and white blood cell count increase; all adverse events were mild, except one episode of sweating (moderate) in a healthy control subject, and all were transient and resolved without any treatment.

\section{Discussion}

The present findings show that a single dose of GHRP-2 elicited reproducible GH secretion in control subjects and that GH response is not influenced by gender but is affected by age and adiposity to some extent. Severe GHD can be diagnosed with high reliability using a cutoff of $15 \mu \mathrm{g} / \mathrm{l}$ for peak serum $\mathrm{GH}$ concentration in patients with both hypothalamic and pituitary diseases. 
Table 3 Peak GH concentrations $\left(C_{\mathrm{max}}\right)$ in response to GH-releasing peptides-2 in patients with GH deficiency compared with control subjects, stratified by age and body mass index.

\begin{tabular}{|c|c|c|c|c|c|c|c|}
\hline \multirow[b]{2}{*}{ Age (years) } & \multirow[b]{2}{*}{ BMI $\left(\mathrm{kg} / \mathrm{m}^{2}\right)$} & \multirow[b]{2}{*}{$n$} & \multicolumn{2}{|c|}{ GHD patient $C_{\max }(\mu \mathrm{g} / \mathrm{l})$} & \multirow[b]{2}{*}{$n$} & \multicolumn{2}{|c|}{ Control subject $C_{\max }(\mu \mathrm{g} / \mathrm{l})$} \\
\hline & & & Mean \pm s.D. & Median (range) & & Mean \pm s.D. & Median (range) \\
\hline \multirow[t]{3}{*}{$17-39$} & $\leq 21.9$ & 10 & $1.7 \pm 2.9$ & $0.35(0.05-9.1)$ & 22 & $121.2 \pm 59.3$ & $115.4(29.9-329.4)$ \\
\hline & $22-24.9$ & 12 & $1.6 \pm 4.2$ & $0.17(0.05-14.8)$ & 14 & $138.1 \pm 81.0$ & $124.5(48.6-345.1)$ \\
\hline & $\geq 25$ & 9 & $1.1 \pm 2.2$ & $0.19(0.05-6.8)$ & 9 & $60.2 \pm 27.8$ & $52.3(24.2-101.2)$ \\
\hline \multirow[t]{3}{*}{$40+$} & $\leq 21.9$ & 5 & $0.63 \pm 0.63$ & $0.48(0.05-1.7)$ & 10 & $67.4 \pm 28.0$ & $64.9(29.2-130.5)$ \\
\hline & $22-24.9$ & 4 & $2.0 \pm 1.8$ & $(0.48-4.2)$ & 19 & $41.9 \pm 21.2$ & $37.0(15.9-85.6)$ \\
\hline & $\geq 25$ & 18 & $1.2 \pm 1.9$ & $0.43(0.05-7.6)$ & 3 & $37.9 \pm 27.2$ & (21.4-69.3) \\
\hline
\end{tabular}

The GHRP-2 test met the criteria reported to be necessary for the validation of a $\mathrm{GH}$ provocative test (29), which are: i) to be potent and reproducible, with reproducibility assessed in normal subjects, ii) the influence of gender, age and adiposity should be validated in control subjects, iii) effectiveness needs to be assessed in controls and patients, evaluated by ROC curve analysis, and iv) the cut-off point for the test should be established by ROC curve analysis and is the value that provides the best pairing of sensitivity and specificity.

The magnitude of GH response to GHRP-2 in control adult subjects was reproducible and consistent with previous studies (30, 31). Rapid GH response to GHRP-2 may reduce the number of blood samples and time required for patients in the investigation unit. In the majority of control subjects, the peak occurred at $30 \mathrm{~min}$ and for most GH-deficient patients, it was earlier, at $15 \mathrm{~min}$, but the $\mathrm{GH}$ values at $30 \mathrm{~min}$ were almost of the same magnitude as the peak values. Therefore, a single 30 min sample would provide similar diagnostic information on peak $\mathrm{GH}$ as that reported for the GHRH plus GHRP test $(14,15,32)$.

Gender had no significant influence on GH response to GHRP-2, but age- and adiposity-affected response in the present study. Previous studies using GHRP-6, hexarelin or ghrelin had shown that gender did not influence the GH response in control subjects $(33,34)$. However, in older subjects aged $49-76$ years, males were reported to respond better to GHRP-2 than females (35), which is in agreement with our findings in control subjects $>60$ years.

With regard to age, our findings that GH response to GHRP-2 was reduced in control subjects over 40 years when compared with younger adults are in agreement with previous studies using hexarelin or ghrelin (33, 34). However, GHRP-6 alone or combined with GHRH was not affected by age $(13,18,36)$. We could not explain why GHRP-6 was apparently not affected by age but GHRP-2 is.

Recent studies have shown that normative values of GH response to GHRH plus GHRP-6 should be defined according to the BMI $(18,19)$. In our study, GH response to GHRP-2 was found to be affected by an increase in BMI. GH response was reduced but remained substantially preserved in control subjects of BMI over $25 \mathrm{~kg} / \mathrm{m}^{2}$. Further investigation is needed to define normative data.

In our analysis of the sensitivity-specificity curves, comparing healthy subjects with GH-deficient patients, the serum GH concentration at the point where sensitivity crossed with specificity, i.e. the value showing high sensitivity and high specificity, ranged from 15 to $20 \mu \mathrm{g} / \mathrm{l}$. The intended use of GHRP-2 is not mass screening but exact diagnosis of subjects highly likely to have the disease. Therefore, it was considered reasonable to set the cut-off value for diagnosis of severe GHD with GHRP-2 at the more stringent level of $15 \mu \mathrm{g} / \mathrm{l}$ and this cut-off value was provided $100 \%$ sensitivity and $100 \%$ specificity. The value was also consistent with results from tests using combined GHRP- 6 and GHRH in lean subjects. GHRP-6 shows a weaker GH stimulating effect than GHRP-2 and requires augmentation with GHRH (37). GHRP and GHRH act through different receptors and have a synergistic effect on GH secretion. Combined administration of GHRH and GHRP-2 has been suggested as a diagnostic test of GH deficiency (16). However, our results may indicate that GHRP-2 alone is sufficient to evoke GH secretion.

The sites of action of GHRP are considered to be both pituitary and hypothalamus. Popovic et al. (38) have shown that about $16 \%$ of patients, who have had cranial radiotherapy may have hypothalamic-pituitary dysfunction, evident from a poor GH response to ITT, and

Table 4 Time to peak serum GH concentration after GHRP-2 stimulation in control subjects and patients with GH deficiency.

\begin{tabular}{llllll}
\hline & & \multicolumn{3}{c}{ Times (min) } \\
\cline { 3 - 5 } & $\boldsymbol{n}$ & 15 & 30 & 45 & 60 \\
\hline Controls & 77 & 13 & 55 & 6 & 3 \\
Patients & 58 & 43 & 14 & 1 & 0 \\
\hline
\end{tabular}




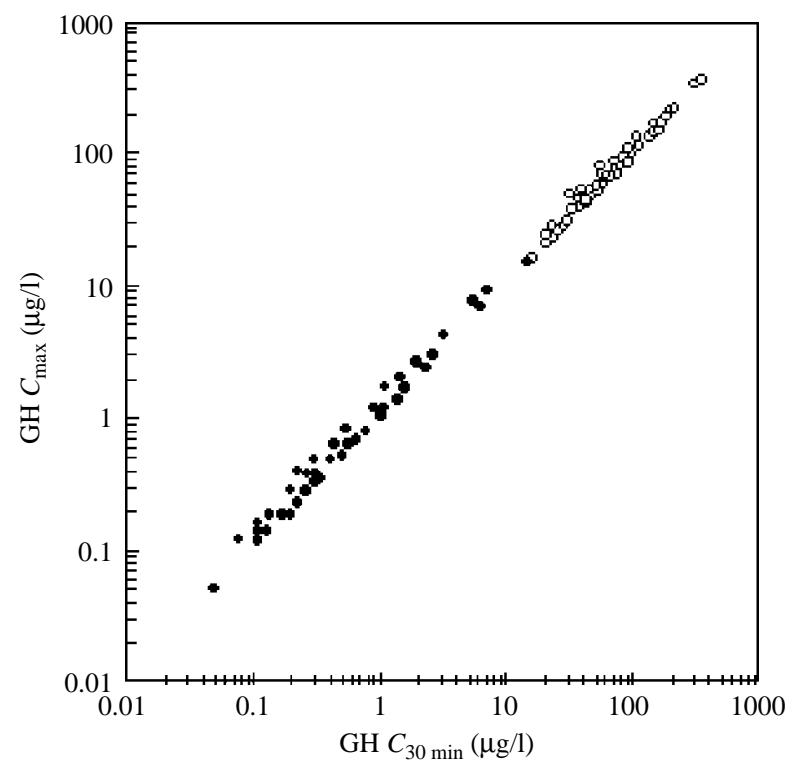

Figure 5 Relationship between serum GH concentration at $30 \mathrm{~min}$ $\left(C_{30} \mathrm{~min}\right)$ and peak concentration $\left(C_{\max }\right)$ after GHRP-2 administration in patients with GHD (closed symbols) and control subjects (open symbols).

exhibit false-positive responses to the combined administration of GHRH plus GHRP-6. The same phenomena were also observed in the case of combined arginine plus GHRH $(11,12)$. The comparative analysis of hypothalamic and pituitary diseases in the present study indicated that GHRP-2 could equally diagnose GHD of both types, similar to the ITT. However, more patients with mild GHD due to hypothalamic lesion are needed to clarify the sensitivity and specificity of GHRP-2 tests.

The adverse reactions observed in the GHRP-2 provocative test were flushing, borborygmus and white blood cell count increase. All were transient and disappeared without treatment, indicating good safety profile of GHRP-2. Flushing and sweating were observed frequently in other studies with $\operatorname{GHRP}(15,30,34)$. The endogenous GH secretagogue, ghrelin, was reported to

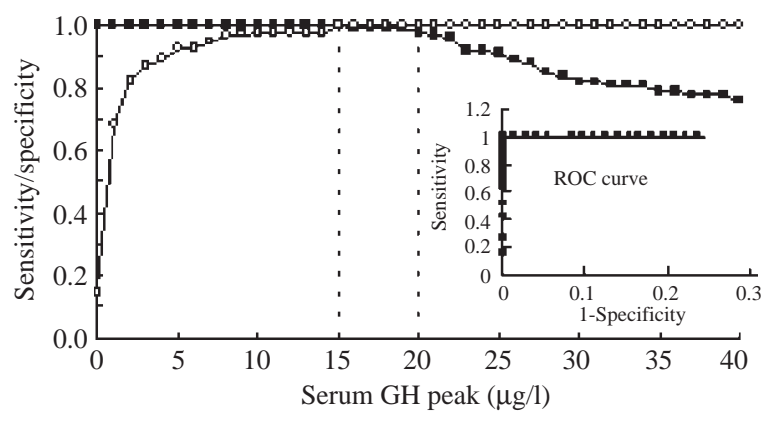

Figure 6 Plot of the variation in sensitivity (open symbols) and specificity (closed symbols) for GH peak following GHRP-2 administration; insert indicates the ROC curve of $\mathrm{GH}$ responses to GHRP-2.
Table 5 Adverse reactions following GHRP-2 administration to healthy control subjects and patients with GH deficiency.

\begin{tabular}{lccc}
\hline & $\begin{array}{c}\text { Controls } \\
(n=77)\end{array}$ & Patients $(n=58)$ & Total $(n=135)$ \\
\hline Hot flush & 14 & 10 & 24 \\
Borborygmus & 8 & 11 & 19 \\
Increased WBC & 5 & 1 & 6 \\
Sweating & 5 & 1 & 6 \\
Nausea & 0 & 2 & 2 \\
Drowsiness & 0 & 3 & 3 \\
Taste perversion & 2 & 0 & 2 \\
Dry mouth & 0 & 2 & 2 \\
Dizziness & 0 & 1 & 1 \\
Others & 0 & 14 & 14 \\
Total adverse & $23(29.9)$ & $31(53.4)$ & $54(40.0)$ \\
$\quad$ reactions $(n(\%))$ & & & \\
\hline
\end{tabular}

enhance digestive tract movement (39) and GHRP-2 has similar effects to ghrelin in increasing appetite in humans (40); the borborygmus probably relates to the physiological effects on gastric motility.

In Japan, the guidelines for diagnosis of GH deficiency, issued by the Hypothalamic-Pituitary Dysfunction Study Group of the Ministry of Health, Labour and Welfare, states that at least two kinds of provocative tests are necessary to diagnose GHD. Diagnostic tests are performed using stimulating agents selected from among insulin, arginine, glucagon and L-DOPA for the diagnosis of adult GH deficiency. When the peak serum GH concentration is $<3 \mu \mathrm{g} / \mathrm{l}$ in at least two different stimulation tests, severe GH deficiency is diagnosed. In the paediatric field, GH stimulating agents include clonidine in addition to those used in adults; severe GH deficiency is diagnosed when the peak serum GH concentration is $<5 \mu \mathrm{g} / \mathrm{l}$ in at least two tests. GHRH has also been used as a diagnostic agent for $\mathrm{GH}$ deficiency, but the test is strongly influenced by the GH secretion-suppressing system (somatostatin). It is thought that many false-negative results are seen, that the $\mathrm{GH}$ response decreases with aging and the reproducibility of $\mathrm{GH}$ secretion is insufficient, with large inter-individual differences. GHRH test is, therefore, not included in the $\mathrm{GH}$ provocative tests specified in the Japanese guidelines. From the present result, we decided to include the GHRP-2 test as an alternative for diagnosing severe GHD in adults.

In conclusion, the provocative test with a single dose of GHRP-2 showed favourable reproducibility and was not influenced by gender. The decreased response with aging or adiposity did not affect the discrimination between healthy control subjects and GH-deficient patients, and the diagnostic capacity of GHRP-2 for severe GHD was very high irrespective of the hypothalamic or pituitary causes of diseases. From the results of this study, we would recommend a GHRP-2 dose of $100 \mu \mathrm{g}$ intravenously and measurement of GH response at $30 \mathrm{~min}$. Maximum specificity and sensitivity was achieved using a diagnostic cut-off value of $15 \mu \mathrm{g} / \mathrm{l}(9 \mu \mathrm{g} / \mathrm{l}$ when 
calibrated with GH standard WHO 98/574 as reference (27)). Subsequent studies are needed to directly compare the utility of GHRP-2 and the combined GHRH plus arginine or GHRH plus GHRP as an alternative to the ITT. We believe that GHRP-2 is a useful and safe alternative diagnostic agent for severe GHD.

\section{Acknowledgements}

We would like to thank Dr Peter Bates, Cambridge Medical Writing Services, CB10 1SH, UK for his help in the preparation of the manuscript. We are also very grateful for the help of the following investigators involved in the study: K Kobayashi, T Tajima, K Sato, K Fujieda, J Nakae, N Shinohara, Department of Pediatrics, Hokkaido University School of Medicine; T Suda, N Tamazawa, T Nigawara, A Sakisaka, Third Department of Internal Medicine, Hirosaki University School of Medicine \& Hospital; M Mori, M Yamada, T Sato, T Monden, First Department of Internal Medicine, Gunma University Hospital; Y Saito, I Tatsuno, D Uchida, Second Department of Internal Medicine, Chiba University Hospital; H Niimi, T Yasuda, Department of Pediatrics, Chiba University Hospital; H Demura, K Takano, K Yasumoto, Second Department of Internal Medicine, Tokyo Women's Medical University; F Marumo, Y Hirata, M Shichiri, T Imai, Second Department of Internal Medicine, Tokyo Medical and Dental University; I Wakabayashi, T Shibasaki, H Sugihara, J Kamei, Y Shuto, S Ishii, Third Department of Internal Medicine, Nippon Medical School; R Horikawa, M Goto, N Ikema, M Ishikawa, Division of Endocrinology and Metabolism, National Center for Child Health and Development; M Ishibashi, M Honda, Fourth Department of Internal Medicine, Teikyo University School of Medicine University Hospital, Mizonokuchi; Y Miyachi, H Ueshiba, First Department of Internal Medicine, Toho University Omori Hospital; H Nakamura, Y Oki, Second Department of Internal Medicine, Hamamatsu University School of Medicine; H Saito, Y Oiso, Y Miura, First Department of Internal Medicine, Nagoya University Hospital; M Ogawa, T Asai, Department of Pediatrics, Nagoya University Hospital; K Yasuda, T Mune, S Daido, Gifu University Hospital; S Ichiyama, S Kosugi, Department of Clinical Laboratory, Kyoto University Hospital; T Usui, Clinical Research Institute, Kyoto National Hospital; M Nishikawa, N Toyoda, Second Department of Internal Medicine, Kansai Medical University; T Sugimoto, H Kaji, Y Okimura, K Iida, M Murata, G Iguchi, H Abe, Department of Clinical Molecular Medicine, Kobe University Graduate School of Medicine; S Kanzaki, Department of Pediatrics, Okayama University School of Medicine; Y Nishi, Department of Pediatrics, Hiroshima Red Cross Hospital \& Atomic-bomb Survivors Hospital; Y Murakami, M Sohmiya, M Nishiki, First Department of Internal Medicine, Shimane University Faculty of Medicine; K Murao, H Hosokawa, S Matsubara, J
Takahara, M Sato, First Department of Internal Medicine, Kagawa University Faculty of Medicine; K Hashimoto, T Takao, T Nishioka, K Asaba, Second Department of Internal Medicine, Kochi Medical School; H Nawata, T Yanase, K Sato, M Nomura, T Okabe, Third Department of Internal Medicine, Kyushu University Faculty of Medicine; S Matsukura, H Katakami, T Yonekawa, Third Department of Internal Medicine, Miyazaki University Faculty of Medicine; T Kohno, Fukuoka Children's Hospital. This work was supported by research grants from Kaken Pharmaceutical Co. Ltd., in part by Health and Labour Grants from the Ministry of Health, Labour and Welfare of Japan and by Grant-in-Aid for Scientific Research (B) and Grant-in-Aid for Exploratory Research from the Ministry of Education, Culture, Sports, Science and Technology of Japan.

\section{References}

1 Shalet SM, Toogood A, Rahim A \& Brennan BM. The diagnosis of growth hormone deficiency in children and adults. Endocrine Reviews 199819 203-223.

2 Consensus guidelines for the diagnosis and treatment of adults with growth hormone deficiency: summary statement of the Growth Hormone Research Society Workshop on Adult Growth Hormone Deficiency. Journal of Clinical Endocrinology and Metabolism 199883 379-381.

3 Jones SL, Trainer PJ, Perry L, Wass JA, Bessser GM \& Grossman A. An audit of the insulin tolerance test in adult subjects in an acute investigation unit over one year. Clinical Endocrinology $1994 \mathbf{4 1}$ $123-128$.

4 Hoeck HC, Vestergaard P, Jacobsen PE \& Laurberg P. Test of growth hormone secretion in adults: poor reproducibility of the insulin tolerance test. European Journal of Endocrinology 1995133 305-312.

5 Fisker S, Jorgenen JO, Orskov H \& Christiansen JS. L-arginine and insulin-tolerance tests in the diagnosis of adult growth hormone deficiency: influence of confounding factors. Clinical Endocrinology 199848 109-115.

6 Vestergaard P, Hoeck HC, Jakobsen PE \& Laurberg PR. Reproducibility of growth hormone and cortisol responses to the insulin tolerance test and the short ACTH test in normal adults. Hormone and Metabolic Research 199729 106-110.

7 Dieguez C \& Casanueva FF. Influence of metabolic substrates and obesity on growth hormone secretion. Trends in Endocrinology and Metabolism 19956 55-59.

8 Ghigo E, Aimaretti G, Gianotti L, Bellone J, Arvat E \& Camanni F. New approach to the diagnosis of growth hormone deficiency in adults. European Journal of Endocrinology $1996134352-356$.

9 Biller BM, Samuels MH, Zagar A, Cook DM, Arafah BM, Bonert V, Stavrou S, Kleinberg DL, Chipman JJ \& Hartman ML. Sensitivity and specificity of six tests for the diagnosis of adult GH deficiency. Journal of Clinical Endocrinology and Metabolism $2002 \mathbf{8 7}$ 2067-2079.

10 Corneli G, Di Somma C, Baldelli R, Rovere S, Gasco V, Croce CG, Grottoli S, Maccario M, Colao A, Lombardi G, Ghigo E, Camanni F \& Aimaretti G. The cut-off limits of the $\mathrm{GH}$ response to GH-releasing hormone-arginine test related to body mass index. European Journal of Endocrinology 2005153 257-264.

11 Darzy KH, Aimaretti G, Wieringa G, Gattamaneni HR, Ghigo E \& Shalet SM. The usefulness of the combined growth hormone (GH)releasing hormone and arginine stimulation test in the diagnosis of radiation-induced $\mathrm{GH}$ deficiency is dependent on the postirradiation time interval. Journal of Clinical Endocrinology and Metabolism $2003 \mathbf{8 8} 95-102$. 
12 Björk J, Link K \& Erfurth EM. The utility of growth hormone (GH) releasing hormone-arginine test for diagnosing $\mathrm{GH}$ deficiency in adults with childhood acute lymphoblastic leukaemia treated with cranial irradiation. Journal of Clinical Endocrinology and Metabolism $2005906048-6054$.

13 Popovic V, Leal A, Micic D, Koppeschaar HP, Torres E, Paramo C, Obradovic S, Dieguez C \& Casanueva FF. GH-releasing hormone and $\mathrm{GH}$-releasing peptide- 6 for diagnostic testing in GH-deficient adults. Lancet $20003561137-1142$.

14 Mahajan T \& Lightman SL. A simple test for growth hormone deficiency in adults. Journal of Clinical Endocrinology and Metabolism 200085 1473-1476.

15 Petersenn S, Jung R \& Beil FU. Diagnosis of growth hormone deficiency in adults by testing with GHRP-6 alone or in combination with GHRH: comparison with the insulin tolerance test. European Journal of Endocrinology 2002146 667-672.

16 Bowers CY. Synergistic release of growth hormone by GHRP and GHRH: scope and implication. In Growth Hormone Secretagogues in Clinical Practice, pp 1-25. Eds BB Bercu \& RF Walker. New York: Marcel Dekker, 1998.

17 Kojima M, Hosoda H, Date Y, Nakazato M, Matsuo H \& Kangawa K. Ghrelin is a growth-hormone-releasing acylated peptide from stomach. Nature $1999 \mathbf{4 0 2} 656-660$.

18 Haijma SV, van Dam PS, de Vries WR, Maitimu-Smeele I, Dieguez C, Casanueva FF \& Koppeschaar HP. The GHRH/GHRP6 test for the diagnosis of GH deficiency in elderly or severely obese men. European Journal of Endocrinology 2005152 575-580.

19 Kelestimur F, Popovic V, Leal A, Van Dam PS, Torres E, Perez Mendez LF, Greenman Y, Koppeschaar HP, Dieguez C \& Casanueva FF. Effect of obesity and morbid obesity on the growth hormone $(\mathrm{GH})$ secretion elicited by the combined GHRH + GHRP-6 test. Clinical Endocrinology $2006 \mathbf{6 4} 667-671$.

20 Deghenghi R, Boutignon F, Luoni M, Grilli R, Guidi M \& Locatelli V. Small peptides as potent releasers of growth hormone. Journal of Pediatric Endocrinology and Metabolism 19958 311-313.

21 Doi N, Hirotani C, Ukai K, Shimada O, Okuno T, Kurasaki S, Kiyofuji T, Ikegami R, Futamata M, Nakagawa T, Ase K \& Chihara K. Pharmacological characteristics of KP-102 (GHRP-2), a potent growth hormone-releasing peptide. Arzneimittel-Forschung $2004 \mathbf{5 4} 857-867$.

22 Nakagawa T, Ukai K, Ohyama T, Koida M \& Okumura H. Effects of the synthesized growth hormone releasing peptide, KP-102, on growth hormone release in sodium glutamate monohydratetreated low growth rats. Life Science $1996 \mathbf{5 9} 705-712$.

23 Examination Committee of Criteria for 'Obesity Disease' in Japan \& Japan Society for the Study of Obesity. New criteria for 'Obesity Disease' in Japan. Circulation Journal $200266987-992$.

24 Shimatsu A, Chihara K, Hizuka N, Teramoto A, Tanaka T, Tatsumi K, Tachibana K, Katsunuma N, Yokoya S \& Fujieda K. Standardized reference intervals of serum insulin-like growth factor-1 in normal adult Japanese population. In Annual Report of the Japan Study Group on the Hypothalamic-Pituitary Dysfunction 2007, pp 39-43. Ed. K Chihara, Tokyo: The Ministry of Health, Labour and Welfare, 2007 (In Japanese).

25 Report of Brain Tumor Registry of Japan (1969-1993). Neurologia Medico-Chirurgica 200040 (suppl.) 1-106.

26 Tanaka T, Takano K, Hanew K, Nishi Y, Igarashi Y, Hirano T, Saito T, Tachibana K, Yokoya S, Fujieda K, Shimatsu A, Hizuka N, Tsushima T \& Irie M. Registration system for growth hormone (GH) treatment with standardized immunoreactive $\mathrm{GH}$ values in Japan. Endocrine Journal 199845 459-465.

27 Tanaka T, Tachibana K, Shimatsu A, Katsumata N, Tsushima T, Hizuka N, Fujieda K, Yokoya S \& Irie M. A nationwide attempt to standardize growth hormone assays. Hormone Research 200564 (suppl 2) 6-11.
28 Bland JM \& Altman DG. Statistical method for assessing agreement between two methods of clinical measurement. Lancet $1986 \mathbf{3 2 7}$ 307-310.

29 Casanueva FF, Pombo M, Leal A, Popovic V \& Dieguez C. Biochemical diagnosis of $\mathrm{GH}$ deficiency in adults. In GHD in Adults: 10 Years of KIMS, pp 91-100. Eds R Abs \& U FeldtRasmussen. London: Oxford Pharma Genesis Ltd, 2004.

30 Arvat E, di Vito L, Maccagno B, Broglio F, Boghen MF, Deghenghi R, Camanni F \& Ghigo E. Effects of GHRP-2 and hexarelin, two synthetic $\mathrm{GH}$-releasing peptides, on $\mathrm{GH}$, prolactin, ACTH and cortisol levels in man. Comparison with the effects of GHRH, TRH and hCRH. Peptides 199718 885-891.

31 Tiulpakov AN, Brook CG, Pringle PJ, Peterkova VA, Volevodz NN \& Bowers CY. GH responses to intravenous bolus infusions of $\mathrm{GH}$ releasing hormone and $\mathrm{GH}$ releasing peptide 2 separately and in combination in adult volunteers. Clinical Endocrinology $1995 \mathbf{4 3}$ 347-350.

32 Leal A, Lage M, Popovic V, Torres E, Koppeschaar HP, Paramo C, Micic D, Garcia-Mayor RV, Dieguez C \& Casanueva FF. A single growth hormone $(\mathrm{GH})$ determination is sufficient for the diagnosis of GH-deficiency in adult patients using the growth hormone releasing hormone plus growth hormone releasing peptide- 6 test. Clinical Endocrinology 200257 377-384.

33 Penalva A, Pombo M, Carballo A, Barreiro J, Casanueva FF \& Dieguez C. Influence of sex, age and adrenergic pathways on the growth hormone response to GHRP-6. Clinical Endocrinology 1993 38 87-91.

34 Broglio F, Benso A, Castiglioni C, Cottero C, Prodam F, Destefanis S, Gauna C, van der Lely AJ, Deghengi R, Bo M, Arvat E \& Ghigo E. The endocrine response to ghrelin as a function of gender in humans in young and elderly subjects. Journal of Clinical Endocrinology and Metabolism 200388 1537-1542.

35 Veldhuis JD, Patrie JT, Brill KT, Weltman JY, Mueller EE, Bowers CY \& Weltman A. Contributions of gender and systemic estradiol and testosterone concentrations to maximal secretagogue drive of burst-like growth hormone secretion in healthy middle-aged and older adults. Journal of Clinical Endocrinology and Metabolism 2004 $896291-6296$.

36 Micic D, Popovic V, Doknic M, Macut D, Dieguez C \& Casanueva FF. Preserved growth hormone $(\mathrm{GH})$ secretion in aged and very old subjects after testing with the combined stimulus GH-releasing hormone plus GH-releasing hexapeptide-6. Journal of Clinical Endocrinology and Metabolism 199883 2569-2572.

37 Pandya N, Mott-Friberg R, Bowers CY, Barkan AL \& Jaffe CA. Growth hormone $(\mathrm{GH})$-releasing peptide 6 requires endogenous hypothalamic GH-releasing hormone for maximal GH stimulation. Journal of Clinical Endocrinology and Metabolism $1998 \mathbf{8 3}$ 1186-1189.

38 Popovic V, Pekic S, Golubicic I, Doknic M, Dieguez C \& Casanueva FF. The impact of cranial irradiation on GH responsiveness to GHRH plus GH-releasing peptide-6. Journal of Clinical Endocrinology and Metabolism $2002872095-2099$.

39 Masuda Y, Tanaka T, Inomata N, Ohnuma N, Tanaka S, Itoh Z, Hosoda H, Kojima M \& Kangawa K. Ghrelin stimulates gastric acid secretion and motility in rats. Biochemical and Biophysical Research Communications $2000 \mathbf{2 7 6} 905-908$.

40 Laferrere B, Abraham C, Russell CD \& Bowers CY. Growth hormone releasing peptide-2 (GHRP-2), like ghrelin, increases food intake in healthy men. Journal of Clinical Endocrinology and Metabolism $200590611-614$.

Received 1 February 2007

Accepted 16 April 2007 